\title{
DECOMPOSITION CHARACTERISTICS AND NUTRIENT RELEASE RULES OF MAIZE STRAW UNDER DIFFERENT RETURNING AMOUNTS
}

\author{
HE, H. - LI, J. H. ${ }^{*}$ - WEI, C. Z. - ZHANG, Y. T. \\ Key Laboratory of Oasis Eco-agriculture, Xinjiang Production and Construction Corps/College \\ of Agronomy, Shihezi University, Road of North 4th, Shihezi City, 832003 Xinjiang, China \\ *Corresponding author \\ e-mail: ljh630703@163.com \\ (Received 21 ${ }^{\text {st }}$ Dec 2018; accepted $20^{\text {th }}$ Feb 2019)
}

\begin{abstract}
The decomposition and nutrient release of maize (Zea mays L.) straw under the four returning amounts of $10.0 \mathrm{~g}$ (CR1), $30.0 \mathrm{~g}$ (CR3), $50.0 \mathrm{~g}$ (CR5), and $70.0 \mathrm{~g}$ (CR7) were studied by nylon mesh bag method, exploring the decomposition characteristics and nutrient releases rules of maize straw, and providing a theoretical basis of rational use of straw resources and nutrient resources management. The results showed that decomposition and the nutrients release of straw are fast in the early stage (0-20 days) and slow in the late stage (20-100 days). In the first 20 days, the $\mathrm{C} / \mathrm{N}$ ratio of the straw decreased the fastest, and the decomposition and nutrient release was the fastest. At the end of the experiment, the $\mathrm{C} / \mathrm{N}$ ratio is relatively stable, the characteristics of decomposition rate and $\mathrm{P}$ and $\mathrm{K}$ releases rules was $\mathrm{CR} 3>\mathrm{CR} 5=\mathrm{CR} 7>\mathrm{CR} 1$, the $\mathrm{C}$ and $\mathrm{N}$ release rate rules were $\mathrm{CR} 3=\mathrm{CR} 5>\mathrm{CR} 7>\mathrm{CR} 1$; the release order of the different nutrients was $\mathrm{K}>\mathrm{P}>\mathrm{N}>\mathrm{C}$; the decomposition and nutrient release of CR3 was the fastest. In summary, a reasonable amount of returning promotes straw decomposition and nutrient release, which are conducive to the rational use of straw resources, and put forward measures of nutrient resource management.
\end{abstract}

Keywords: straw returning, maize planting, decomposition stage, nutrients, C/N ratio, rational use, nutrient resources management

\section{Introduction}

In recent years, the extensive application of chemical fertilizers has led to agricultural non-point source pollution, soil ecosystem damage and other issues. The crop straw is an important biological in crop production and contains rich plant nutrients and organic carbon. Straw returning is of great significance for improving soil fertility, reducing fertilizer application, reducing agricultural non-point source pollution and improving soil ecosystem (Jin and Zhou, 2018). Many studies have shown the straw returning to the field reduces the use of chemical fertilizers by releasing nutrients from crop straw decomposing, which is an important technology for green agriculture, ecological agriculture and environmental agriculture (Chen et al., 2018; Streets, 2006; Shibu et al., 2006). Straw returning is of great significance for improving soil nutrient, increasing resource use, reducing environmental pollution and improving ecological environment (Jin and Xing, 2018; Witt et al., 2000; Lal, 2010; Hu et al., 2012), so, it is an important way to the rational use of straw resources and sustainable development of agriculture.

To speed up the development and promotion of straw returning technology, some research on straw decomposition is increasing. Studies have shown the crop straw requires the combined action of microorganisms and enzymes to decompose (Becker et al., 2014; Ji et al., 2014). When the straw enters the soil, the decomposition rate of straw increases gradually with time, and the speed of straw decomposition decreases 
gradually, which is faster in the early stage and slower in the latter stage (Dai et al., 2010; Huang et al., 2016; Ji et al., 2013). The study found the different crops have different speeds of decomposition, for example, maize straw is faster than wheat (Zheng et al., 2004). Some studies have shown the amount of straw returning is negatively correlated with the rate of decomposition, and the application of decomposition agents can significantly speed up the decomposition and mineralization rate of straw (Jusoh et al., 2013; Chen et al., 2011). However, the application of chemical fertilizers in the soil can also promote to decompose of straw (Zheng et al., 2004). Soil fertility affects the decomposition rate of maize straw and high fertility promotes decomposition (Wang et al., 2009). The decomposition rate of crop straw mainly depends on the $\mathrm{C} / \mathrm{N}$ ratio, and the decomposition is obviously accelerated after the $\mathrm{C} / \mathrm{N}$ ratio is lowered (Zhang et al., 1994). About nutrient release rate of straw, studies have shown that characteristic is $\mathrm{P}>\mathrm{K}>\mathrm{N}>\mathrm{C}$ (Dai et al., 2010; Ji et al., 2013), but some studies have found that is $\mathrm{K}>\mathrm{P}>\mathrm{C}>\mathrm{N}$ (Zhong et al., 2017). The depth of straw application also influences on the release of nutrients, the release rate of $\mathrm{N}, \mathrm{P}$ and $\mathrm{K}$ in the deep application of straw is faster than the surface application (Douglas et al., 1980). It can be seen that are many studies on straw decomposition, but a few studies on the amount of straw returning. Thus, it is of great significance to study the straw decomposition at different returning amounts.

Most studies on straw decomposing use the nylon mesh bag method (Olson and Krawczyk, 1963; Dai et al., 2010; Nakajima et al., 2016). Our study was carried out in the arid area using the nylon mesh bag method, because it has little effect on soil water transport, it is close to the actual situation in the field, and is more suitable for studying the decomposition of crop straw in arid and semi-arid areas (Lin et al., 1992). Yining County is the major maize producing area in Xinjiang, China. It has a large planting area, excessive use of chemical fertilizers in production, rich maize straw resources but low use rate; therefore, straw returning has enormous potential. Exploring the decomposition characteristics and nutrient $(\mathrm{C}, \mathrm{N}, \mathrm{P}$, and $\mathrm{K})$ releases rules of maize straw under different returning amounts of maize planting, and providing a theoretical basis of rational use of straw resources and nutrient resource management.

\section{Materials and methods}

\section{Experimental site description}

This experimental site was located in Yining County Modern Agricultural Technology Demonstration Park in Xinjiang, China $\left(43^{\circ} 55^{\prime} \mathrm{N}, 81^{\circ} 33^{\prime} \mathrm{E}\right.$; altitude is 843 $\mathrm{m})$. The county is temperate desert climate, which is mild and humid in the winter and spring, and warm and dry in the summer and autumn. The annual average temperature is $10.6{ }^{\circ} \mathrm{C}$, and the annual maximum temperature is $35.8{ }^{\circ} \mathrm{C}$. Annual precipitation is from $250 \mathrm{~mm}$ to $550 \mathrm{~mm}$, the frost-free period is 154 days to 184 days, the annual average sunshine hours are $2792.7 \mathrm{~h}$, and the effective accumulated temperature $\geq 10^{\circ} \mathrm{C}$ is $3621.2^{\circ} \mathrm{C}$ (10 years of data). Air temperature, precipitation and soil temperature during the experimental period in 2018 (Fig. 1).

The curve represents air temperature $\left({ }^{\circ} \mathrm{C}\right)$ and soil temperature $\left({ }^{\circ} \mathrm{C}\right)$, and the bar represents 20 days of accumulative precipitation $(\mathrm{mm})$. Air temperature $\left({ }^{\circ} \mathrm{C}\right)$ and daily average soil temperature $\left({ }^{\circ} \mathrm{C}\right)$ are recorded once a week and recorded 20 days of accumulative precipitation $(\mathrm{mm})$ every 20 days. The meteorological data are from local meteorological departments. 

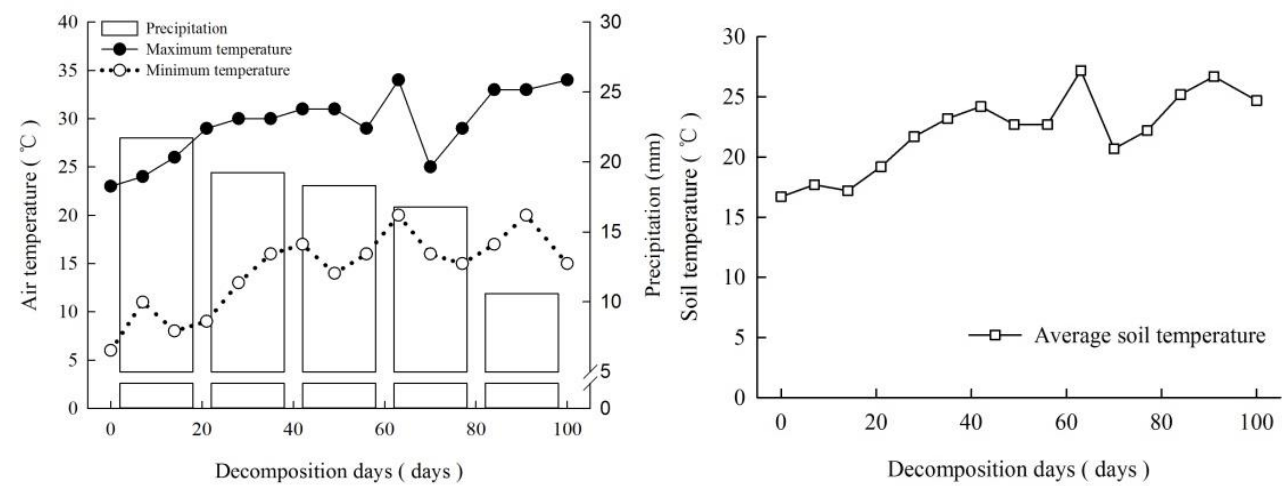

Figure 1. Temperature and precipitation during the experimental period

\section{Experimental materials}

The soil type of the experiment area is the irrigated sierozem, and the basic physical and chemical properties of the ploughed soil $(0-20 \mathrm{~cm}): \mathrm{pH}$ of $7.71(1: 2.5 \mathrm{soil} / \mathrm{water}$ ratio), soil organic matter (SOM) of $12.73 \mathrm{~g} \mathrm{~kg}^{-1}$, total nitrogen (TN) of $0.96 \mathrm{~g} \mathrm{~kg}^{-1}$, alkali-hydrolyzable nitrogen (AN) of $85.95 \mathrm{mg} \mathrm{kg}^{-1}$, available phosphorus (AP) of 23.94 $\mathrm{mg} \mathrm{kg}{ }^{-1}$, and available potassium (AK) of $229.24 \mathrm{mg} \mathrm{kg}^{-1}$, soil C/N ratio of 13.26.

The experimental straw was maize (Zea mays L.) straw (comprised the stems and leaves) preserved after harvest in 2017, and its initial nutrient contents were as follows: $\mathrm{C} / \mathrm{N}$ ratio of 28.13 , organic $\mathrm{C}(\mathrm{C})$ of $413.50 \mathrm{~g} \mathrm{~kg}^{-1}$, total $\mathrm{N}(\mathrm{N})$ of $19.47 \mathrm{~g} \mathrm{~kg}^{-1}$, total $\mathrm{P}$ (P) of $3.09 \mathrm{~g} \mathrm{~kg}^{-1}$, total $\mathrm{K}(\mathrm{K})$ of $17.53 \mathrm{~g} \mathrm{~kg}^{-1}$. Fertilizers used included urea $(46.0 \% \mathrm{~N})$, diammonium phosphate $\left(18.0 \% \mathrm{~N}, 48.0 \% \mathrm{P}_{2} \mathrm{O}_{5}\right)$, potassium sulfate $\left(51.0 \% \mathrm{~K}_{2} \mathrm{O}\right)$, and organic fertilizer $\left(1.77 \% \mathrm{~N}, 1.95 \% \mathrm{P}_{2} \mathrm{O}_{5}, 0.53 \% \mathrm{~K}_{2} \mathrm{O}\right)$.

\section{Experimental design}

The plot experiment was conducted from May 8, 2018, to August 16, 2018. There were three plots with a plot area of $33.2 \mathrm{~m}^{2}(4 \mathrm{~m} \times 8.3 \mathrm{~m})$. Maize (Zea mays cv. Xinyu 50) was planted with the plot, the row spacing was $50 \mathrm{~cm}$ (8 rows), the plant spacing was $21.5 \mathrm{~cm}$, and the planting density was $9.3 \times 10^{4}$ plants ha ${ }^{-1} .469 .5 \mathrm{~kg}$ urea ha ${ }^{-1}$, $333.0 \mathrm{~kg}$ diammonium phosphate $\mathrm{ha}^{-1}, 103.5 \mathrm{~kg}$ potassium sulfate $\mathrm{ha}^{-1}$ and $1350.0 \mathrm{~kg}$ organic fertilizer ha ${ }^{-1}$ were applied to the soil (total fertilization amounts: $300.0 \mathrm{~kg} \mathrm{~N}^{-}$ 1, $180.0 \mathrm{~kg} \mathrm{P}_{2} \mathrm{O} \mathrm{ha} \mathrm{ha}^{-1}, 60.0 \mathrm{~kg} \mathrm{~K}_{2} \mathrm{O} \mathrm{ha}{ }^{-1}$ ). Each plot had four different straw returning amount treatments: $10.0 \mathrm{~g}$ (CR1), $30.0 \mathrm{~g}$ (CR3), $50.0 \mathrm{~g}$ (CR5) and $70.0 \mathrm{~g}$ (CR7), with 5 repetitions. Maize straw (comprised the stems and leaves) is dried and pulverized into 3 $\mathrm{cm}$ to $5 \mathrm{~cm}$, mixed and weighed $(10.0 \mathrm{~g}, 30.0 \mathrm{~g}, 50.0 \mathrm{~g}$, and $70.0 \mathrm{~g}$, respectively), and placed them in a nylon mesh bag (length $\times$ width is $30 \mathrm{~cm} \times 20 \mathrm{~cm}$, pore diameter $0.125 \mathrm{~mm}$ ) and tightened the bag mouth, and the net bag is about $2 \mathrm{~cm}$ high when leveled. Each returning amount is 15 bags, a total of 60 bags ( 3 plots $\times 4$ treatment $\times 5$ repetitions).

The specific operation steps of the buried bag: at the center of each plot, between the 2-6 rows ( 5 rows $\times 4$ treatment), the nylon mesh bags of each treatment is completely randomly buried below the plough layer for $10 \mathrm{~cm}$ (Fig. 2A). When landfilling, the soil $10 \mathrm{~cm}$ depth between rows of maize is taken out, the soil deep in the $2 \mathrm{~cm}$ is dug out (no landfill), then the nylon mesh bag is laid horizontally (the distance between the two 
rows of maize is $15 \mathrm{~cm}$ ), and then the soil is filled back and compacted to the level with the ground (Fig. 2B).

The experimental period was 100 days, and 12 nylon mesh bags were taken every 20 days ( 4 bags were randomly taken out from each plot). To avoid interference from topdressing on determines the nutrient content of maize straw residue; no topdressing was carried out in the area where straw was buried.

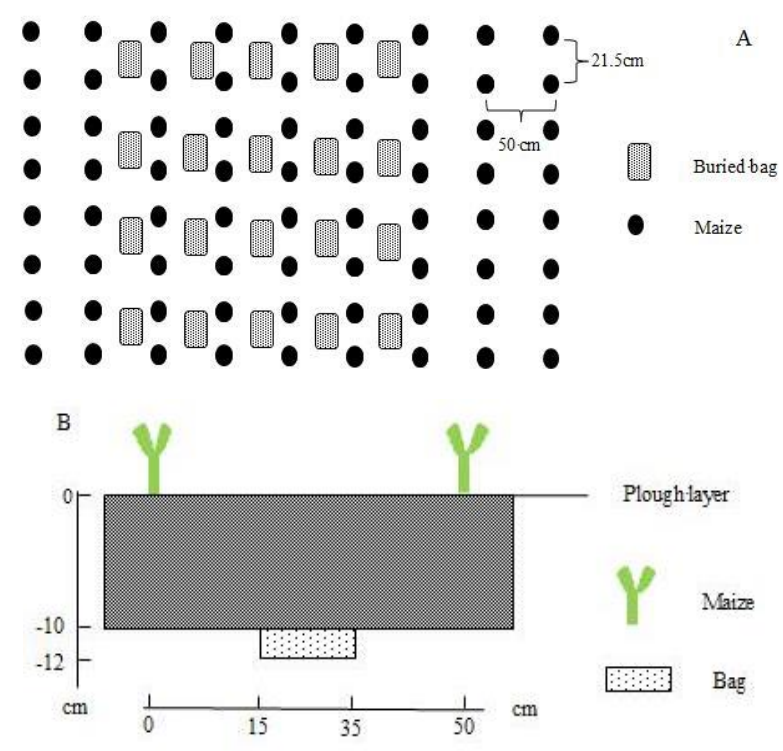

Figure 2. Schematic diagram of the buried bag of maize straw in the plot. A and B are schematic diagrams of buried mesh bags in the plot and vertical cross-sections of the buried mesh bags, respectively

\section{Sampling and chemical analysis}

Sampling began on May 28, 2018, and ended on August 16, 2018, the sampling is 5 times (20, 40, 60, 80, and 100 days of decomposition days). After each sampling, remove the floating soil and root debris on the surface of the nylon mesh bag, rinse the nylon mesh bag and dry it in an oven $\left(65^{\circ} \mathrm{C}\right)$ (KJ-DY02, Kejie Company, China) to constant weight. The straw was removed, weighed, pulverized and sieved (pore size of $1 \mathrm{~mm}$ ) to determine the contents of $\mathrm{C}, \mathrm{P}, \mathrm{N}$ and $\mathrm{K}$.

Determination of organic $\mathrm{C}(\mathrm{C})$ by $\mathrm{K}_{2} \mathrm{Cr}_{2} \mathrm{O}_{7}$ dichromate-external heating method (133 mmol L-1 $\mathrm{K}_{2} \mathrm{Cr}_{2} \mathrm{O}_{7}$ at $\left.170-180{ }^{\circ} \mathrm{C}\right)$, The straw samples $(0.25 \mathrm{~g})$ were digested by the $\mathrm{H}_{2} \mathrm{SO}_{4}-\mathrm{H}_{2} \mathrm{O}_{2}$ method, the total $\mathrm{N}$ in the digestate was measured with an automatic Kjeldahl nitrogen determiner (K9840, Hanon Company, China), the total P (P) in the digestate determined by vanadium molybdate yellow-visible spectrophotometric $(722 \mathrm{~N}$, JKI Company, China), the total $\mathrm{K}(\mathrm{K})$ in the digestate was measured with automatic digital flame photometer (FP640N, OEM Company, China). All methods have been described by Bao (2000).

\section{Calculation and statistical analysis}

Calculate the decomposition rate, decomposition speed, nutrient release rate, and C/N ratio methods (Dai et al., 2010; Yue et al., 2016) (Eqs. 1-4): 


$$
\begin{gathered}
\text { Decomposition rate }(\%)=\frac{M_{0}-M_{t}}{M_{0}} \times 100 \% \\
\text { Decomposition speed }\left(\mathrm{g}^{\mathrm{day}^{-1}}\right)=\frac{M_{0}-M_{\mathrm{t}}}{t} \\
\text { Nutrient release rate }(\%)=\frac{M_{0}-C_{0}-M_{\mathrm{t}}-C_{\mathrm{t}}}{M_{0}-C_{0}} \times 100 \% \\
\mathrm{C} / \mathrm{N} \text { ratio }=\frac{C_{\mathrm{t}}(\mathrm{C})}{C_{\mathrm{t}}(\mathrm{N})}
\end{gathered}
$$

where $M_{0}(\mathrm{~g})$ is the initial dry weight of the straw; $t$ (day) is the decomposition day; $M_{t}$ $(\mathrm{g})$ is the dry weight of straw at $t ; C_{0}\left(\mathrm{~g} \mathrm{~kg}^{-1}\right)$ is the initial nutrient $(\mathrm{C} \mathrm{N}, \mathrm{P}$, and $\mathrm{K})$ content of the straw; $C_{t}\left(\mathrm{~g} \mathrm{~kg}^{-1}\right)$ is the nutrient $(\mathrm{C} \mathrm{N}, \mathrm{P}$, and $\mathrm{K})$ content of the straw at $t$.

All analyses were carried out on the replicates. Statistical analysis was completed using the SPSS 17.0 software. Statistically significant differences were identified using analysis of variance (one-way ANOVA) and Duncan's multiple range tests. Differences were considered significant at $P<0.05$.

\section{Results}

\section{Decomposition characteristics of maize straw}

With the increase of decomposition days, the decomposition rate of maize straw gradually increases, and the decomposition speed gradually decreases, it is fast in the early stage (0-20 days) and slows in the late stage (20-100 days) (Table 1). In the first 20 days, the decomposition speed was the highest and the decomposition rate was higher. The decomposition rates increased to the increase in returning amounts, ranging from $17.07 \%$ to $27.55 \%$, accounting for $36.97 \%$ to $58.20 \%$ of the total decomposition rate, and the characteristics of decomposition rate were $\mathrm{CR} 7=\mathrm{CR} 5=\mathrm{CR} 3>\mathrm{CR} 1$. At the $40^{\text {th }}$ days, there was no significant $(P>0.05)$ difference in the decomposition rate of each treatment, range from $28.43 \%$ to $36.68 \%$. The decomposition speed gradually decreased, CR7 and CR5 decreased faster than CR1 and CR3. After 100 days of decomposition, CR3 was the fastest, the decomposition rate reached 53.94\%, CR1 was the slowest, and the decomposition rate was $46.17 \%$, and CR3 decomposition rate was $7.77 \%, 3.79 \%$, and $6.60 \%$ higher than CR1, CR5, and CR7, respectively, and the characteristics of the decomposition rate was CR3 $>$ CR5 $=\mathrm{CR} 7>\mathrm{CR} 1$. The entire decomposition process, when the same decomposition days, the decomposition speed increases significantly $(P<0.05)$ with the increase in returning amounts, and the characteristics of decomposition speed were CR7 > CR5 > CR3 > CR1.

\section{Nutrient releases rules of maize straw}

With the increase of decomposition days, the nutrient releases rate of the straw increased, and the $\mathrm{C}, \mathrm{N}, \mathrm{P}$ and $\mathrm{K}$ release rate was fast in the early stage (0-20 days) and slow in the later stage (20-100 days) (Fig. 3), which was similar to the characteristics of decomposition (Table 1). In the first 20 days, the nutrient releases rate increased from the increase in the returning amount. The C, N, P and $\mathrm{K}$ released $16.95 \%$ to $29.16 \%$, $17.35 \%$ to $29.87 \%, 23.55 \%$ to $33.93 \%$, and $46.04 \%$ to $53.13 \%$, respectively, accounting for $36.18 \%$ to $59.26 \%, 34.76 \%$ to $57.11 \%, 42.45 \%$ to $59.97 \%$, and $51.43 \%$ to $58.85 \%$ 
of the total release rate, respectively, the rules of $\mathrm{C}, \mathrm{N}$ and $\mathrm{P}$ releases rate were $\mathrm{CR} 7=\mathrm{CR} 5=\mathrm{CR} 3>\mathrm{CR} 1$, the $\mathrm{K}$ release rate was not significant $(P>0.05)$. As the decomposition progresses, the releases speed decreased slowly, at $40^{\text {th }}$ days, the nutrient releases speed of CR7 and CR5 decreased faster than CR3, and was gradually lower than CR3, and at $60^{\text {th }}$ days, and the nutrient release rate of CR3 was higher than CR1, CR5, and CR7. After 100 days of decomposition, the C, N, P, and K release rates reached $46.85 \%$ to $56.51 \%, 49.92 \%$ to $59.69 \%, 55.48 \%$ to $63.23 \%$, and $86.64 \%$ to $100.00 \%$, respectively. Among them, the nutrient release rate of CR3 was the highest, and the release rates of $\mathrm{C}, \mathrm{N}, \mathrm{P}$, and $\mathrm{K}$ of $\mathrm{CR} 3$ were $3.61 \%$ to $9.66 \%, 3.73 \%$ to $9.77 \%$, $3.76 \%$ to $7.75 \%$, and $6.58 \%$ to $13.36 \%$ higher than CR1, CR5, and CR7, respectively. The rules of $\mathrm{C}$ and $\mathrm{N}$ release rate were CR3 $=\mathrm{CR} 5>\mathrm{CR} 7>\mathrm{CR} 1$ (Fig. 3A-B), and the rules of $\mathrm{P}$ and $\mathrm{K}$ release rate were $\mathrm{CR} 3>\mathrm{CR} 5=\mathrm{CR} 7>\mathrm{CR} 1$ (Fig. $3 C-D$ ).
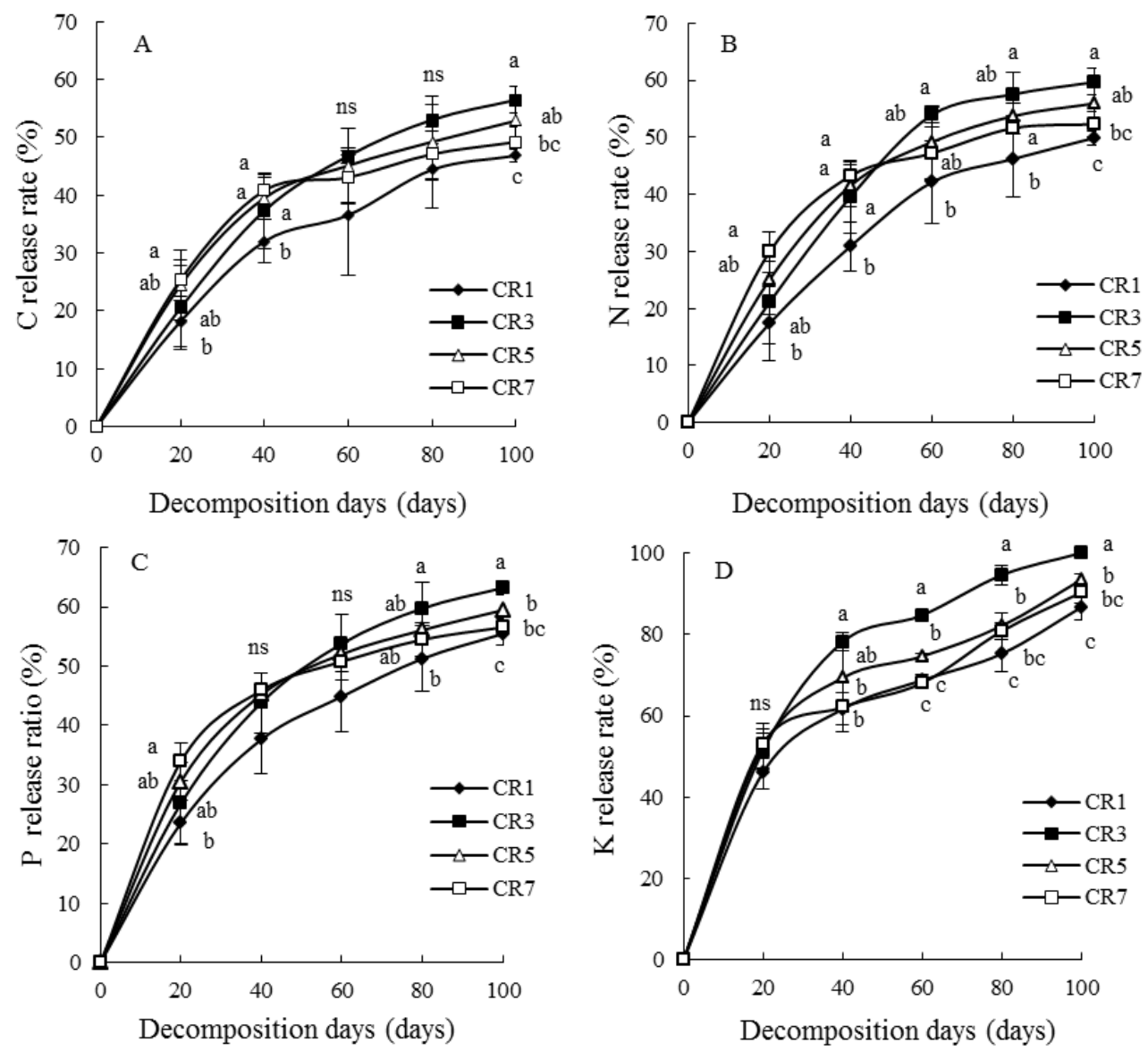

Figure 3. Nutrient releases rate of maize straw under different straw returning amounts. $A, B$, $C$, and $D$ is the nutrient release rate of $C, N, P$, and $K$, respectively. The data represent the mean values of three replicate $\pm S D(n=3)$, and different lowercase letters next to the mean value show a significant difference at $P<0.05, n s=$ not significant. Error bars show the $S D$

$$
(n=3)
$$

In the whole decomposition, according to the nutrient release rules of different treatments (Fig. 3) and comparing the nutrient release rates of different treatments, we can be found the release order of different nutrients was $\mathrm{K}>\mathrm{P}>\mathrm{N}>\mathrm{C}$ (Table 2). 
Table 1. Decomposition characteristics of maize straw under different straw returning amounts

\begin{tabular}{c|c|c|c|c|c}
\hline Treatment & $\mathbf{2 0}^{\text {th }}$ days & $\mathbf{4 0}^{\text {th }}$ days & $\mathbf{6 0}^{\text {th }}$ days & $\mathbf{8 0}^{\text {th }}$ days & $\mathbf{1 0 0}^{\text {th }}$ days \\
\hline \multicolumn{7}{c}{ Decomposition rate $(\%)$} \\
CR1 & $17.07 \pm 3.89 \mathrm{~b}$ & $28.43 \pm 6.79 \mathrm{a}$ & $37.03 \pm 7.55 \mathrm{~b}$ & $44.13 \pm 5.39 \mathrm{~b}$ & $46.17 \pm 2.04 \mathrm{c}$ \\
$\mathrm{CR} 3$ & $20.40 \pm 6.83 \mathrm{ab}$ & $33.79 \pm 5.08 \mathrm{a}$ & $46.47 \pm 2.78 \mathrm{a}$ & $51.04 \pm 2.77 \mathrm{a}$ & $53.94 \pm 0.25 \mathrm{a}$ \\
$\mathrm{CR} 5$ & $24.05 \pm 3.59 \mathrm{ab}$ & $35.37 \pm 5.87 \mathrm{a}$ & $43.37 \pm 3.82 \mathrm{ab}$ & $47.21 \pm 2.32 \mathrm{ab}$ & $50.15 \pm 2.13 \mathrm{~b}$ \\
$\mathrm{CR} 7$ & $27.55 \pm 3.15 \mathrm{a}$ & $36.68 \pm 2.70 \mathrm{a}$ & $40.21 \pm 2.15 \mathrm{ab}$ & $44.05 \pm 0.82 \mathrm{~b}$ & $47.34 \pm 1.50 \mathrm{bc}$ \\
\hline \multicolumn{7}{c}{ Decomposition speed $\left(\mathbf{g ~ d a y}^{-1}\right)$} \\
\hline \multicolumn{7}{c}{ CR1 } & $0.08 \pm 0.02 \mathrm{~d}$ & $0.07 \pm 0.02 \mathrm{~d}$ & $0.06 \pm 0.02 \mathrm{~d}$ & $0.05 \pm 0.01 \mathrm{~d}$ & $0.05 \pm 0.01 \mathrm{~d}$ \\
CR3 & $0.31 \pm 010 \mathrm{c}$ & $0.25 \pm 0.04 \mathrm{c}$ & $0.23 \pm 0.02 \mathrm{c}$ & $0.19 \pm 0.01 \mathrm{c}$ & $0.16 \pm 0.00 \mathrm{c}$ \\
CR5 & $0.60 \pm 0.09 \mathrm{~b}$ & $0.44 \pm 0.08 \mathrm{~b}$ & $0.36 \pm 0.03 \mathrm{~b}$ & $0.29 \pm 0.02 \mathrm{~b}$ & $0.25 \pm 0.01 \mathrm{~b}$ \\
CR7 & $0.96 \pm 0.11 \mathrm{a}$ & $0.64 \pm 0.05 \mathrm{a}$ & $0.47 \pm 0.03 \mathrm{a}$ & $0.39 \pm 0.01 \mathrm{a}$ & $0.33 \pm 0.01 \mathrm{a}$ \\
\hline
\end{tabular}

Values are means $\pm \mathrm{SD}(\mathrm{n}=3)$. Mean values followed by different letters in the same column show signification differences at $P<0.05$

Table 2. The order of nutrient release at different decomposition days

\begin{tabular}{c|c|c|c|c}
\hline \multirow{2}{*}{$\begin{array}{c}\text { Decomposition } \\
\text { day }\end{array}$} & \multicolumn{4}{|c}{ The ranking order of nutrient release } \\
\cline { 2 - 5 } & 1st & 2nd & 3rd & 4th \\
\hline $20^{\text {th }}$ days & $\mathrm{K}(46.04 \%-53.13 \%)$ & $\mathrm{P}(23.55 \%-33.93 \%)$ & $\mathrm{N}(17.35 \%-29.87 \%)$ & $\mathrm{C}(16.95 \%-29.16 \%)$ \\
$40^{\text {th }}$ days & $\mathrm{K}(61.65 \%-78.11 \%)$ & $\mathrm{P}(37.65 \%-45.93 \%)$ & $\mathrm{N}(30.91 \%-43.27 \%)$ & $\mathrm{C}(28.76 \%-40.86 \%)$ \\
$60^{\text {th }}$ days & $\mathrm{K}(68.74 \%-84.70 \%)$ & $\mathrm{P}(44.88 \%-53.80 \%)$ & $\mathrm{N}(42.14 \%-53.92 \%)$ & $\mathrm{C}(38.26 \%-49.77 \%)$ \\
$80^{\text {th }}$ days & $\mathrm{K}(75.25 \%-94.55 \%)$ & $\mathrm{P}(51.26 \%-59.75 \%)$ & $\mathrm{N}(46.22 \%-57.56 \%)$ & $\mathrm{C}(44.42 \%-53.06 \%)$ \\
$100^{\text {th }}$ days & $\mathrm{K}(86.64 \%-100.00 \%)$ & $\mathrm{P}(55.48 \%-63.23 \%)$ & $\mathrm{N}(49.92 \%-59.69 \%)$ & $\mathrm{C}(46.85 \%-56.54 \%)$ \\
\hline
\end{tabular}

The values in parentheses show the range of nutrient $(\mathrm{C}, \mathrm{N}, \mathrm{P}$, and $\mathrm{K})$ content in different treatments

\section{Dynamic change of $C / N$ ratio of maize straw}

In the first 20 days, the $\mathrm{C} / \mathrm{N}$ ratio decreased rapidly with the increase of decomposition days and the decomposition and nutrient releases of straw were the fastest, the $\mathrm{C} / \mathrm{N}$ ratio ranged from 21.15 to 22.72 , and it is 5.41 to 6.98 lower than the initial value (Table 1; Fig. 3). After 40 days, the $\mathrm{C} / \mathrm{N}$ ratio of CR5 and CR7 increased first and then gradually stabilized, ranging from 22.71 to 22.81 , CR1 and CR3 increased first and then decreased, and gradually stabilized after 80 days. At the end of the decomposition, the $\mathrm{C} / \mathrm{N}$ ratio ranging from 22.64 to 23.02 , among them, the $\mathrm{C} / \mathrm{N}$ ratio of CR3 is higher than CR1, CR5 and CR7 by 0.38, 0.21 and 0.31 , respectively (Fig. 4). Similar to the decomposition and nutrient release of CR3 was higher than other treatments at the end of decomposition (Table 1; Fig. 3).

\section{Discussion}

\section{Decomposition characteristics of maize straw}

With the increase of decomposition days, the decomposition rate increased, and the decomposition speed decreased, and the decomposition characteristics of straw were fast in the early stage (0-20 days) and slow in the late stage (20-100 days), which was 
consistent with some researches (Dai et al., 2010; Ji et al., 2013; Zheng et al., 2004; Che et al., 2013; Chen et al., 2011). The reasons may be: on the one hand, maize straw contains a large amount of easily decomposed organic substances in the early stage, such as polysaccharides, amino acids, organic acids. It provides plentiful energy and nutrients for the life activities of soil microorganisms, and improves the activity and quantity of soil microorganisms, thus promoting the decomposition of maize straw. As the straw is decomposed, the remaining major organic substances are difficult to decompose, such as lignin and cellulose, which are difficult to be used by soil microorganisms, resulting in a decrease in microbial activity and a slow decomposition of straw in the later stage (Summerell and Burgess, 1989; Li et al., 2009). On the other hand, the experiment began in May, because of the climate characteristics of the experimental site (Fig. 1), the air temperature and soil temperature gradually increased, and the average precipitation was high, which improved microbial activity, promoted the decomposition of straw. With the increase of decomposition days, the temperature and soil temperature was too high, the precipitation decreases, which weaken microbial activity and metabolic activity, inhibiting the decomposition of straw (Summerell and Burgess, 1989; Nakajima et al., 2016; Azam et al., 1991). Besides, it applied organic fertilizer and chemical fertilizer in maize planting in the plot, which improved soil nutrients. In the early stage of decomposition, maize grew slowly. With the increase of decomposition days, maize grows rapidly and reduces the content of available nutrients, thus inhibiting microbial activity and slowing decomposition. We can see that the decomposition of maize straw is affected by the climate such as temperature, precipitation, and field management, which is consistent with research by Wang et al. (2016). Some studies have shown that pre-decomposition speed is fast, it too slows the medium-term decomposition speed down, and the late decomposition is stagnant (Kuang et al., 2012; Li et al., 2001).

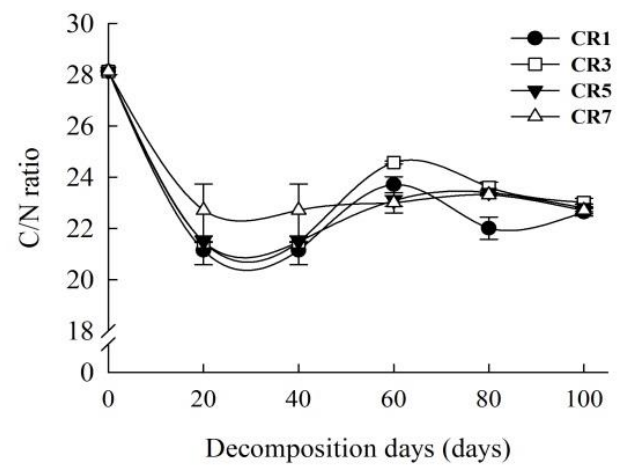

Figure 4. Variation characteristics of the $C / N$ ratio of maize straw under different straw returning amounts. The data represent the mean values of three replicate $\pm S D(n=3)$. Error bars show the $S D(n=3)$

\section{Nutrient releases rules of maize straw}

This study found the release rules of nutrients $(\mathrm{C}, \mathrm{N}, \mathrm{P}$, and $\mathrm{K})$ of different treatments were fast in the early stage (0-20 days) and slow in the late stage (20-100 days), which is similar to the characteristics of decomposition. In the first 20 days, the decomposition rate, decomposition speed and nutrient release rate of different treatments increased with the increase of the amounts of returning, which is consistent 
with Yue et al. (2016) research on the decomposition experiment of maize straw and wheat (Triticum aestivum L.) straw. At the end of the experiment, the nutrient release rate of the treatments with higher decomposition rate was also higher, which is the same result as some studies have found a positive correlation between decomposition rate and nutrients release rate (Dai et al., 2010; Ji et al., 2013; Zheng et al., 2004). We found that when the returning amounts were greater than $30.0 \mathrm{~g}$, the decomposition rate was negatively correlated with the returning amounts, some studies have also shown this result (Zheng et al., 2004). We found the returning amounts were $30.0 \mathrm{~g}$, and its decomposition and nutrient release was the fastest, which is similar to Yue et al. (2016) result of the decomposition and nutrient release of maize straw was the fastest when the amount of maize straw returned was $26.3 \mathrm{~g}$. Therefore, the proper amount of returning is conducive to the decomposition and nutrient release of straw.

This study showed the release of nutrients under different returning amount was $\mathrm{K}>\mathrm{P}>\mathrm{N}>\mathrm{C}$, which is consistent with some studies (Dai et al., 2010; Xu et al., 2010; Gong et al., 2018). In addition, Ji et al. (2013) studies showed that nutrient release of rapeseed (Brassica napus L.) and wheat (Triticum aestivum L.) straw was $\mathrm{K}>\mathrm{P}>\mathrm{N} \approx \mathrm{C}$. Some studies have also found the release rate of maize straw by different decomposers was $\mathrm{K}>\mathrm{P}>\mathrm{C}>\mathrm{N}$ (Zhong et al., 2017; Yang et al., 2016). Therefore, nutrient release rules of different crop straw are different. The release rate of nutrients depends mainly on the morphology of the elements in the straw. Among them, the $\mathrm{K}$ is mainly in the ionic state in cells or plant tissues and is easily soluble in water, so the release rate is the fastest, final cumulative release rate is also the highest; The content of $\mathrm{P}$ is less than $\mathrm{K}$, which is mainly in the insoluble organic state, so the rate of $\mathrm{K}$ release is slower than $\mathrm{P}$ (Wang et al., 2013; Dai et al., 2017); The $\mathrm{N}$ mainly comprises insoluble organic matter, which is decomposed faster in the early stage, and is more difficult to decompose in the later stage, resulting in a decrease in decomposition rate (Murayama et al., 2010); The $\mathrm{C}$ mainly exists in various organic compounds, the decomposition rate is different (Tang et al., 2016). The $\mathrm{C}$ and $\mathrm{N}$ are the main ingredients of straw, the degree of cementation is high, and it is difficult to decompose, resulting in the slower release (Ji et al., 2013; Devêvre et al., 2000). Therefore, there are differences in the nutrient release. This study shows the rule of nutrient release was $\mathrm{K}>\mathrm{P}>\mathrm{N}>\mathrm{C}$.

\section{Dynamic change of $\mathrm{C} / \mathrm{N}$ ratio of maize straw}

The speed of decomposition of straw mainly depends on $\mathrm{C} / \mathrm{N}$ ratio, and the decrease of $\mathrm{C} / \mathrm{N}$ ratio has a certain promoting effect on decomposition (Zhang, 1994), when C/N ratio is large, it affects the rapid growth and metabolism of microorganisms, so the process of straw decomposition is inhibited (Ding et al., 2008). The initial C/N ratio of maize straw is 28.13 , and the best $\mathrm{C} / \mathrm{N}$ ratio of microbial activity ranges from 25 to 30 (Devêvre et al., 2000). In addition, fertilization and proper temperature and precipitation also promote microbial activity, which promotes the decomposition of straw and rapid release of $\mathrm{C}$ and $\mathrm{N}$; therefore, the $\mathrm{C} / \mathrm{N}$ ratio decreases rapidly (Summerell and Burgess, 1989; Zhou et al., 2015; Nakajima et al., 2016). As decomposition progresses, the C/N ratio rise first and then are relatively stable, which because of the same as the reason for straw decomposition and nutrients release. Although the $\mathrm{C} / \mathrm{N}$ ratio is close to the proper range of microbial growth, the $\mathrm{C}$ and $\mathrm{N}$ in the straw are mainly organic substances that are difficult to be used by microorganisms, and the $\mathrm{N}$ content needed for microbial metabolism in the soil is not enough, which reduces the microbial activity, leading to 
slower decomposition and nutrient release (Summerell and Burgess, 1989; Li et al., 2009; Rao et al., 1976). At the end of the decomposition, the decomposition and nutrients release was faster when the $\mathrm{C} / \mathrm{N}$ ratio was higher. The dynamic change of $\mathrm{C} / \mathrm{N}$ ratio in the process of decomposition cannot only reflect the characteristics of straw decomposition and the rules of nutrient releases, but also the speed of decomposition and nutrient release of different treatments.

\section{Rational use of straw resources and nutrient resource management}

The proper amount of returning is conducive to the decomposition and the nutrients release of straw and promotes the rational use of straw resources. According to this study found the characteristics of decomposition and the rules of nutrients release of straw are fast in the early stage (0-20 days) and slow in the late stage (20-100 days), which can properly reduce the use of base fertilizer, and carry out topdressing during the period when maize needs fertilizer, and effectively use fertilizers. According to the rule of nutrient release $(\mathrm{K}>\mathrm{P}>\mathrm{N}>\mathrm{C})$, the release of $\mathrm{P}$ and $\mathrm{K}$ are faster, $\mathrm{P}$ and $\mathrm{K}$ fertilizer can reduce the $\mathrm{K}$ fertilizer or delay the application period of $\mathrm{P}$ and $\mathrm{K}$ fertilizers; Because of the slow release of $\mathrm{N}$ and the decrease of soil $\mathrm{N}$ content in the later stage, $\mathrm{N}$ fertilizers should be applied in time for maize growth and to promote the decomposition of straw.

\section{Conclusions}

Our study concludes that, at the end of the decomposition, the decomposition and nutrient release of CR3 (30.0 g) are the fastest under different returning amounts, therefore, the proper amount of returning is conducive to the decomposition and the nutrients release of maize straw; In the whole decomposition, the characteristics of decomposition and the rules of nutrients $(\mathrm{C}, \mathrm{N}, \mathrm{P}$, and $\mathrm{K}$ ) release of straw under different returning amount are fast in the early stage (0-20 days) and slow in the late stage (20-100 days), and the release order of the different nutrients was $\mathrm{K}>\mathrm{P}>\mathrm{N}>\mathrm{C}$; Proposed that proper amount of returning in maize planting can reduce the amount of base fertilizer used, and the nutrients resource management measures to reduce or delay the application of $\mathrm{P}$ and $\mathrm{K}$ fertilizers and timely applied $\mathrm{N}$ fertilizers.

\section{Prospect}

According to the characteristics of decomposition and the nutrient release rules of straw, guiding scientific straw returning is conducive to the rational use of straw resources and to reduce fertilizer uses. In agricultural production, the characteristics of crops needed for fertilizer should be fully considered, and a reasonable amount of straw returning and nutrient resources management measures should be planned. Therefore, we will conduct a comprehensive study on the characteristics of crop fertilizer need and reasonable straw returning, to further guide the rational use of resources in agricultural production.

Acknowledgements. The National Key Research and Development Program of China (2017YFD0201808), the National Natural Science Foundation of China (31660598, 31360501) supported the research. 


\section{REFERENCES}

[1] Azam, F., Lodhi, A., Ashraf, M. (1991): Availability of soil and fertilizer nitrogen to wetland rice following wheat straw amendment. - Biology and Fertility of Soils 11(2): 97-100.

[2] Bao, S. D. (2000): Analysis of Soil Agrochemical. 3rd Ed. - China Agriculture Press, Beijing.

[3] Becker, R., Bubner, B., Remus, R., Wirth, S., Ulrich, A. (2014): Impact of multi-resistant transgenic Bt maize on straw decomposition and the involved microbial communities. Applied Soil Ecology 73(1): 9-18.

[4] Che, J. M. L., Abd, M. L., Abdul, L. P. (2013): Composting of rice straw with effective microorganisms (EM) and its influence on compost quality. - Iranian Journal of Environmental Health Science and Engineering 10(1): 17-17.

[5] Chen, H., Zhang, X. Y., Hao, X. S. (2018): Research progress of multiple effects of straw returning on farmland environment. - Jiangsu Agricultural Sciences 46(5): 21-24.

[6] Chen, Y. J., Zhou, J. H., Qiang, L. I., Xie, Y., Liu, J. H. (2011): Decomposition characteristics of stalk decomposition accelerator on different crop-stalks. - Hunan Agricultural Sciences.

[7] Dai, W., Gao, M., Lan, M., Huang, R., Wang, J., Wang, Z. (2017): Nutrient release patterns and decomposition characteristics of different crop straws in drylands and paddy fields. - Chinese Journal of Eco-Agriculture 25(2): 188-199.

[8] Dai, Z. G., Lu, J. W., Li, X. K., Lu, M. X., Yang, W. B., Gao, X. Z. (2010): Nutrient release characteristic of different crop straws manure. - Transactions of the Chinese Society of Agricultural Engineering 26(6): 272-276(5).

[9] Devêvre, O. C., Horwath, W. R. (2000): Decomposition of rice straw and microbial carbon use efficiency under different soil temperatures and moistures. - Soil Biology and Biochemistry 32(11): 1773-1785.

[10] Ding, X. L., Hong-Bo, H. E., Xiao-Bo, L. I., Bai, Z., Xie, H. T., Zhang, X. D. (2008): Effect of nitrogen level on carbon mineralization and microbial biomass during initial decomposition of maize straw. - Chinese Journal of Soil Science 39(4): 784-788.

[11] Douglas, C. L. J., Allmaras, R. R., Rasmussen, P. E., Ramig, R. E., Roager, N. C. J. (1980): Wheat straw composition and placement effects on decomposition in dryland agriculture of the Pacific Northwest. - Soil Science Society of America Journal 44(4): 833-837.

[12] Gong, Z., Deng, N., Song, Q., Li, Z. (2018): Decomposing characteristics of maize straw returning in Songnen Plain in long-time located experiment. - Transactions of the Chinese Society of Agricultural Engineering 34(8): 139-145.

[13] Hu, H. X., Cheng, Y., Ma, Y. H., Yu, X. S., Xiang, J. X. (2012): Decomposition characteristics of returned rapeseed straw in soil and effects. - Chinese Journal of EcoAgriculture 20(3): 297-302.

[14] Huang, J., Duan, Z. N., Peng, M. A. (2016): Decomposition and nutrient release characteristics of rapeseed and wheat straws incorporated into paddy soil. - Journal of Anhui Agricultural Sciences 18: 139-141.

[15] Ji, B., Hu, H., Zhao, Y., Mu, X., Liu, K., Li, C. (2014): Effects of deep tillage and straw returning on soil microorganism and enzyme activities. - The Scientific World Journal. http://dx.doi.org/10.1155/2014/451493.

[16] Ji, W. U., Guo, X., Jianwei, L. U., Wan, S., Wang, Y., Zhengyu, X. U. (2013): Decomposition characteristics of wheat straw and effects on soil biological properties and nutrient status under different rice cultivation. - Acta Ecologica Sinica 33(2): 565-575.

[17] Jin, S. Q., Xing, X. X. (2018): Trend analysis, policy evaluation, and recommendations of agricultural non-point source pollution. - Scientia Agricultura Sinica 51(3): 593-600.

[18] Jin, S., Zhou, F. (2018): Zero growth of chemical fertilizer and pesticide use: China's objectives, progress and challenges. - Journal of Resources and Ecology 9(1): 50-58. 
[19] Jusoh, M. L. C., Manaf, L. A., Latiff, P. A. (2013): Composting of rice straw with effective microorganisms (EM) and its influence on compost quality. - Iranian Journal of Environmental Health Science and Engineering 10(2): 17-17.

[20] Kuang, E. J., Chi, F. Q., Qing-Rui, S. U., Zhang, J. M., Jin, L. (2012): Decomposition characteristics of maize straws under different returning methods. - Journal of Maize Sciences 2: 99-106.

[21] Lal, R. (2010): Managing soils for a warming earth in a food-insecure and energy-starved world. - Journal of Plant Nutrition and Soil Science 173(1): 4-15.

[22] Li, F. Y., Sun, X. F., Feng, W. Q., Wang, C. Q., Tu, S. H. (2009): Nutrient release patterns and decomposing rates of wheat and rapeseed straw incorporated into the field. Plant Nutrition and Fertilizer Science 15(2): 374-380.

[23] Li, X. J., Zhang, Z. G., Li, Y. X. (2001): Effects of soil depth on decay speed of straw. Acta Pedologica Sinica 38(1): 135-138.

[24] Lin, X. X., Wu, S. L., Che, Y. P. (1992): Nylon bag method for determination of decomposition rate of organic matter in arid and semi-dry regions. - Soils 24(6): 315318.

[25] Murayama, S. (2010): Decomposition kinetics of straw saccharides and synthesis of microbial saccharides under field conditions. - J Soil Sci 35(2): 231-242.

[26] Nakajima, M., Cheng, W., Tang, S., Hori, Y., Yaginuma, E., Hattori, S. (2016): Modeling aerobic decomposition of rice straw during the off-rice season in an Andisol paddy soil in a cold temperate region of japan: effects of soil temperature and moisture. - Soil Science and Plant Nutrition 7(1): 1-9.

[27] Olson, H. H., Krawczyk, G. R. (1963): Procaine penicillin G in milk following intramuscular injections. - Jour Dairy Sci 46(2): 155-157.

[28] Rao, D. N., Mikkelsen, D. S. (1976): Effect of rice straw incorporation on rice plant growth and nutrition. - Agronomy Journal 68(5): 752-755.

[29] Shibu, M. E., Leffelaar, P. A., Keulen, H. V., Aggarwal, P. K. (2006): Quantitative description of soil organic matter dynamics-a review of approaches with reference to rice-based cropping systems. - Geoderma 137(1): 1-18.

[30] Streets, D. G. (2006): Black smoke in China and its climate effects. - Asian Economic Papers 4(2): 1-23.

[31] Summerell, B. A., Burgess, L. W. (1989): Decomposition and chemical composition of cereal straw. - Soil Biology and Biochemistry 21(4): 551-559.

[32] Tang, S., Cheng, W., Hu, R., Guigue, J., Kimani, S. M., Tawaraya, K. (2016): Simulating the effects of soil temperature and moisture in the off-rice season on rice straw decomposition and subsequent $\mathrm{CH}_{4}$, production during the growth season in a paddy soil. - Biology and Fertility of Soils 52(5): 739-748.

[33] Wang, J., Changai, L. U., Zhang, W., Feng, G., Wang, X., Minggang, X. U. (2016): Decomposition of organic materials in cropland soils across China: a meta analysis. Acta Pedologica Sinica. DOI: 10.11766/trxb201503090019.

[34] Wang, X. D., Chen, X. N., Wang, C. X., Tian, X. H., Wu, F. (2009): Decomposition of corn stalk in cropland with different fertility. - Transactions of the Chinese Society of Agricultural Engineering 25(10): 252-257.

[35] Wang, Y. Z., Chen, X., Shi, Y. (2013): Phosphorus availability in cropland soils of china and related affecting factors. - Chinese Journal of Applied Ecology 24(1): 260.

[36] Witt, C., Cassman, K. G., Olk, D. C., Biker, U., Liboon, S. P., Samson, M. I. (2000): Crop rotation and residue management effects on carbon sequestration, nitrogen cycling and productivity of irrigated rice systems. - Plant and Soil 225(1/2): 263-278.

[37] Xu, R. L., Wang, J. F., Zhang, G. L., Dai, Q. G. (2010): Changes of microbe and organic matter content in paddy soil applied with straw manure and nitrogen fertilizer. - Acta Ecologica Sinica 30(13): 3584-3590. 
[38] Yang, L., Zhou, M., Deng, X., Tian, F., Zhang, M., Chen, Z. (2016): Decomposition rate and nutrient release of corn stalk treated with different decomposition maturing agents. Chinese Agricultural Science Bulletin 32(30): 32-27.

[39] Yue, D., Cai, L. Q., Qi, P., Zhang, R. Z., Wu, J., Gao, X. L. (2016): Decomposition characteristics and nutrient release characteristics of wheat and maize straw under different returning amount. - Journal of Arid Land Resources and Environment 30(3): $80-85$.

[40] Zhang, F. D. (1994): Decomposition and transformation of 14 C-traced straw in soils. Plant Nutrition and Fertilizing Science 268(2): 537-545.

[41] Zheng, D. M., Jiang, Y. J., Shuang-Qing, L. U., Zhu, C. Y. (2004): Study on decomposition and humification coefficient of organic fertilizer in arid region. - Soils and Fertilizers (2): 15-19.

[42] Zhong-Yi, L. I., Tang, H. Q., Meng, Y. C., Tie-Guang, H. E., Wang, J., Jun-Ming, H. U. (2017): Characteristics of decomposition and nutrients release of dolichos lablab L'straw under different incorporation methods. - Soil and Fertilizer Sciences in China 2017(2): 114-135. DOI: $10.11838 /$ sfsc. 20170218.

[43] Zhou, G. X., Chen, L., Zhang, C. Z., Zhang, J. B. et al. (2015): Effects of temperature and moisture on microbial community function responsible for straw decomposition. - Soils 47(5): 911-918. 